\section{A bumpy ride?}

Two articles in this issue are distinctly provocative. The first is by Morton Benson of the University of Pennsylvania, who takes on no less a giant than TESOL, an organization whose annual conventions attract thousands of teachers of English as a Second Language. Then Thomas Paikeday in Toronto boldly goes where few would dare, doubting that the International Phonetic Alphabet provides useful dictionary pronunciations. As Benson says: 'Fasten your seat belts; it's going to be a bumpy ride.'

Also in this issue we end our series on corpora and concordancing. It began in ET28 (Oct 91) with Sidney Greenbaum's report from London on ICE (the International Corpus of English); it has included three articles by Michael Rundell and Penny Stock of Longman; and closes with a contribution by Geoffrey Leech of Lancaster on the British National Corpus. It is followed here by another high-tech piece, from Stephen Boyd Davis of Middlesex University, on hypertext and multimedia, key features of electronic life in the 1990s.

In addition, I am happy to say that at last we can offer a detailed insight into English as it is used in South Africa, provided by Rajend Mesthrie of the University of Cape Town. A number of readers have asked for such an article, and to celebrate our breakthrough we are publishing not only this general article but also in April a second piece by the same researcher on South African Indian English, a complex variety that combines elements of pidgin and standard usage with influences from both Indian and African languages.

The supporting cast remains as strong and as varied as ever. Among them are Martin Bennett, writing from Saudi Arabia on Arabic words in English at large, Dale Roberts in North Carolina taking over our Kaleidoscope section, and Dennis Baron of the University of Illinois on idiosyncratic phone numbers and names in the US. Finally, alongside a bumper crop of reviews by John Algeo, Jack Miller, Raymond Chapman and Paul Christophersen, Roshan McArthur wins the battle of the bulge in Recent Titles by bringing our list of books received decently up to date. Although further books arrive just about every day from the publishers' cornucopia, I can now pretend that we're on top of them rather than having them on top of us.

\section{Tom McArthur}

The editorial policy of English Today is to provide a focus or forum for all sorts of news and opinion from around the world. The points of view of individual writers are as a consequence their own, and do not reflect the opinion of the editorial board. In addition, wherever feasible, ET generally leaves unchanged the orthography (normally British or American) and the usage of individual contributors, although the editorial style of the journal itself is that of Cambridge University Press.
(C) Cambridge University Press 1993. No contents may be reproduced by any means without the permission of Cambridge University Press.

English Today (ISSN 0266-0784) is a quarterly. ISBN 0521448395

Publisher: Cambridge University Press, Edinburgh Building, Shaftesbury Road, Cambridge CB2 2RU. Telephone (0223) 312393 Subscriptions: the current annual subscription price for four issues for libraries and institutions is $£ 44$ outside North America; $£ 21$ for individuals; $\Sigma 17$ for students and the retired; airmail £10 per year extra. Apply to Jane Crossiand at the above address.

Advertising Sales: write to Nicholas Kelly at the above address.

USA, CANADA AND MEXICO:

Publisher: Cambridge University Press, 40 West 20th Street, New York, NY 10011-4211. Telephone (212) 9243900.

Subscriptions: the current annual subscription price in USA, Canada and Mexico for libraries and institutions is $\$ 73$; $\$ 34$ for individuals; $\$ 24$ for students and the retired. Copies are air-freighted to New York to arrive with minimum delay. Apply to Lynda DiCaprio at the above address.

Advertising Sales: write to Julia Hess at the above address.

Second class postage paid at New York, NY and at additional mailing offices.

POSTMASTER: send address changes in USA, Canada and Mexico to English Today,

Cambridge University Press, 110 Midland Avenue, Port Chester, New York, NY 10573-9864.

Japanese prices for institutions (including ASP delivery) are available from Kinokuniya Company Ltd, P.O. Box 55, Chitose, Tokyo.

Letters to the Editor: write to Dr Tom McArthur, Editor, English Today, 22-23 Ventress Farm Court, Cherry Hinton Road, Cambridge CB1 4HD, UK.

A call for papers: In ET s files we have cuttings/clippings from a wide range of British and North American newspapers, and a scattering of material from many other sources. If readers would care to add to our files by sending in occasional (titled and dated) materials from their local newspapers, etc., this would be a great help in widening the range of usage which we can quote.

Printed in Great Britain at the University Press, Cambridge 